\title{
ПІДХОДИ ДО НАДАННЯ ПАЛІАТИВНОЇ ДОПОМОГИ ДІТЯМ І ПІДЛІТКАМ З ОНКОЛОГІЧНОЮ ПАТОЛОГІЄЮ: РОЛЬ МЕДИЧНИХ СЕСТЕР
}

\author{
I. В. Сивоконенко ${ }^{1}$, Н. Б. Галіяш ${ }^{2}$ \\ ${ }^{1}$ ТОВ «Сімейна клініка психічного здоров'я «Рехаб Фемелі Украӥна» \\ ${ }^{2}$ Тернопільський національний медичний університет \\ імені І. Я. Горбачевського МОЗ Украӥни
}

\begin{abstract}
Педіатрична паліативна допомога має на меті покращити життя та зменшити страждання дітей і підлітків, які живуть зі загрозою для життя, та їхніх близьких. Медичні сестри, які працюють в онкологічних відділеннях, мають важливе значення у наданні паліативної допомоги дітям і підліткам 3 онкологією. У статті описано підходи до надання паліативної допомоги дітям та подано огляд літератури, пов’язаної з фізичною, психологічною, соціальною та духовною сферами паліативного догляду за дітьми та підлітками, хворими на рак.
\end{abstract}

\section{APPROACHES TO PROVIDING PALLIATIVE CARE TO CHILDREN AND ADOLESCENTS WITH ONCOLOGICAL PATHOLOGY: THE ROLE OF NURSES}

\author{
I. V. Syvokonenko' ${ }^{1}$ N. B. Haliyash ${ }^{2}$ \\ ${ }^{1}$ LLC "Family Mental Health Clinic "Rehab Family Ukraine" \\ ${ }^{2}$ I. Horbachevsky Ternopil National Medical University
}

\begin{abstract}
Pediatric palliative care aims to enhance life and decrease suffering of children and adolescents living with lifethreatening conditions and their loved ones. Oncology nurses are instrumental in providing palliative care to pediatric oncology populations. This paper describes pediatric palliative care and provides an overview of literature related to the physical, psychological, social, and spiritual domains of palliative nursing care for children and adolescents with cancer.
\end{abstract}

Вступ. Смерть дитини - це «унікальна трагедія» [1]. На жаль, у Сполучених Штатах Америки від раку щорічно помирає 53000 дітей [2]. В Україні ситуація теж невтішна: за даними Всесвітньої організації охорони здоров'я, щороку рак виявляють у тисячі український дітей [3]. Найпоширеніше злоякісне захворювання - рак крові. Лише $47 \%$ пацієнтів виліковують, на відміну від 70 \% показника на Заході. Це свідчить про те, що кожна друга дитина помирає від раку [4].

Діти, які живуть з раком, можуть зазнати значних страждань. Ініціативи щодо поліпшення якості життя та зменшення страждань пацієнтів дитячої онкології та їхніх близьких представлені запровадженням команд із паліативної допомоги в дитячих онкологічних установах у США та інших географічних регіонах, таких, як Ліван, Ізраїль, Велика Британія тощо

(C) І. В. Сивоконенко, Н. Б. Галіяш, 2021
[5-8]. В Україні, попри значні зусилля щодо її розвитку, система паліативного догляду за дітьми все ще недосконала: допомога надається в лікувальних закладах за профілем захворювання дитини медичним персоналом, який зазвичай не має достатніх вмінь і умов для надання саме такої допомоги $[4,9]$. Важливим $є$ підвищення рівня знань лікарів й інших медпрацівників щодо особливостей роботи з невиліковно хворими дітьми і членами їхніх сімей та створення мультидисциплінарних команд фахівців для надання паліативної допомоги в медичних закладах різного рівня.

Тому метою даної роботи стало здійснити огляд літератури щодо фізичного, психологічного, соціального та духовного аспектів паліативної допомоги дітям та підліткам, хворим на рак, які можуть надавати медсестри, та з'ясувати їх роль у забезпеченні такої допомоги. 
Основна частина. За визначенням Всесвітньої організації охорони здоров'я, паліативна допомога - це підхід, що дозволяє поліпшити якість життя пацієнтів та їхніх сімей, які стикнулися з проблемами смертельного захворювання, шляхом запобігання i полегшення страждань завдяки ранньому виявленню, ретельній оцінці й лікуванню болю та інших фізичних симптомів, а також наданню психосоціальної та духовної підтримки [1]. Паліативна допомога забезпечує пацієнтам полегшення симптомів, болю та стресу від тяжкого чи невиліковного захворювання; має на меті покращити якість життя як пацієнта, так і його сім'ї; включає мультидисциплінарну команду лікарів, медсестер та інших клініцистів, які працюють разом з іншими спеціалістами, щоб запропонувати додатковий рівень підтримки; підходить для будь-якого віку та на будь-якій стадії тяжкої хвороби; може співіснувати як з лікуванням, спрямованим на видужання, так і з хоспісним доглядом. Паліативна допомога дітям спеціально визначається Національною організацією хоспісної та паліативної допомоги як «філософія та організований метод надання компетентного, співчутливого та послідовного догляду за дітьми з хронічними, складними та/або такими, що загрожують життю, станами та їх родинами» [10].

Метою педіатричної паліативної допомоги $\epsilon$ покращення життя, полегшення страждань, оптимізація функцій та забезпечення можливостей особистісного зростання для дітей зі загрозливими для життя захворюваннями, такими, як рак, та належна підтримка членів їхніх сімей. Цілісний підхід, передбачений сімейно-орієнтованою моделлю дитячої паліативної допомоги, стимулює залучення сімей до взаємовигідного та підтримуючого партнерства. Зосереджуючись на цілісному підході, необхідно враховувати чотири сфери, що випливають із визначення дитячої паліативної допомоги: фізичну, психологічну, соціальну та духовну [11].

\section{Фізична сфера паліативної допомоги дітям}

Фізичний вимір дитячої паліативної допомоги включає управління болем та симптомами і повинен бути наріжним каменем допомоги дітям, які стикаються з раком. У пацієнтів спостерігають симптоми, пов'язані з діагнозом, стадією захворювання та терапевтичними втручаннями. Симптоми змінюються у відповідь на первинне та паліативне лікування і часто вимагають повторної оцінки стану та потреб дитини. Може знадобитися фармакологічне та нефармакологічне лікування болю, задишки, нудоти та блювоти, підвищеної секреції та судоми. Важливість забезпечення своєчасного лікування болю та симптомів $є$ добре визнаною та вивченою в паліативній допомозі. Хоча інтеграція програм дитячої паліативної допомоги показала зменшення страждань у дітей та підлітків, які помирають від раку, сильний дистрес залишається поширеним.

Втомлюваність, біль, задишка, нудота та анорексія відзначаються як найпоширеніші фізичні симптоми, які спостерігають у дітей, хворих на рак. Утім найчастіші симптоми не завжди є найтяжчими або найстресовішими для пацієнтів дитячої онкології. Деякі дослідження повідомляють, що відчуття втоми зменшується у 10-18-річних дітей, які перебувають на мієлосупресивній хіміотерапії, та в 10-17-річних, які були госпіталізовані протягом 5 днів [12]. Інші підлітки (віком 10-19 років), хворі на рак, повідомляли про часті симптоми втоми протягом хіміотерапії. Вона асоціюється з підвищеною тривожністю, смутком та страхом наприкінці життя, але залишається недооціненим і недолікованим симптомом у дітей з онкологією [13].

Нудота та блювота - ще один поширений та тривожний симптом, який спостерігають у дітей та підлітків з онкологічними захворюваннями, часто пов'язаний із госпіталізацією чи хіміотерапією. Підлітки, які страждають від раку, повідомляли, що нудота залишалася наявною протягом 5-ти днів госпіталізації. Інші підлітки вважали, що нудота стає більш тяжкою під час хіміотерапії [14]. Діти молодшого віку часто залежать від свого основного опікуна в аспекті оцінки та вираження своїх фізичних симптомів.

Протоколи щодо лікування болю та симптомів у дитячій онкології були розроблені задля полегшення середнього та сильного болю, який відчувають діти. Ці програми включали навчання як медичного персоналу, так і батьків, а також рекомендації щодо вдосконалення оцінки болю та його лікування в дитячій онкології. Дослідження вивчали фармакологічні стратегії для забезпечення оптимального зняття болю для дітей, хворих на рак [15].

Численні дослідження підкреслюють багатовимірний характер симптомів, що поєднує підходи до контролю симптомів, особливо з прогресуванням раку. Існують рекомендації щодо вдосконалення лікування симптомів у пацієнтів дитячої онкології, проте потреби в кращій оцінці, вимірі, документації та лікуванні багатьох фізичних симптомів все ще залишаються. 


\section{Психологічна сфера паліативної допомоги дітям}

Психологічний вимір дитячої паліативної допомоги для онкохворих дитини чи підлітка полягає в тому, як дитина почуває себе, в механізмі подолання стресу, загальному сприйнятті якості життя, а також горя та емоцій, пов'язаних із діагнозом, що загрожує життю [16]. У дітей можуть виникати думки про смерть, які часто проявляються їх фантазіями та іграми. Команда паліативної допомоги може надати відповідну підтримку залежно від рівня розвитку, щоб допомогти дітям, хворим на рак, пережити відчуття, пов'язані з їх хворобою, а в деяких випадках і можливістю смерті [17].

Розуміння медсестрами психологічних аспектів дитячого раку значно зросло за останні 30 років, поступившись місцем психологічним втручанням, спрямованим на зменшення психологічних переживань (наприклад тривожності, депресії) та покращення їх подолання і психологічної адаптації (наприклад навичок вирішення проблем, освітнього функціонування) [18]. Розробка ефективних вказівок, що стосуються емоцій, горя та страхів, пов'язаних із смертю, дуже необхідна для цієї групи пацієнтів. Діти, підлітки та їхні сім'ї стикаються з незліченною кількістю стресових факторів від моменту встановлення діагнозу до виживання або завершення життя та втрати. Все ще залишаються прогалини в розумінні спектра емоцій, які переживають діти зі загрожуючими життю станами, та механізмів подолання, що задіяні протягом хвороби.

\section{Соціальна сфера паліативної допомоги дітям}

Соціальний вимір дитячої паліативної допомоги $\epsilon$ ще одним важливим елементом для підвищення якості життя онкохворої дитини при підтримці сім'ї. Соціальні аспекти передбачають взаємодію дитини або ізоляцію від інших, практичні реалії та соціальні наслідки для сім'ї [16]. Дослідження, зосереджені на соціальних наслідках для членів сім'ї після смерті дитини, показують глибокі та довготривалі результати.

Соціальна підтримка дітей зі загрозливими для життя станами може надаватися через соціальні мережі чи інші засоби постійної взаємодії з іншими дітьми з подібними захворюваннями, членами сім'ї або іншими дорослими, які відіграють важливу роль у їхньому житті [16]. Факти свідчать про те, що соціальна взаємодія, а також наявність часу на самоті можуть призвести до позитивних результатів для госпіталізованих онкологічних дітей. Підлітки, які страждають від раку, усвідомили, що групи підтримки надають можливість взаємодіяти з іншими хворими однолітками, давати та отримувати натхнення та бути нормальним підлітком [19].

Увага та турбота, що присвячені вмираючій дитині, стають частиною довготривалого впливу на тих, хто вижив. Батьки поділилися тим, що вони відчували, що на практиці бракує груп підтримки для дітей, які пережили втрату брата чи сестри, як і програм для психологічного відновлення, а вони $\epsilon$ вкрай необхідними [11].

\section{Ауховна сфера паліативної допомоги дітям}

Духовний вимір дитячої паліативної допомоги стосується того, як дитина розуміє сенс переживання [19]. Духовність стає в центрі уваги, коли людина стикається з емоційним стресом, фізичним захворюванням або смертю. Такі запитання, як «Чому Бог це робить?» або «як там, на небі?» виникають часто [16]. У дитинстві духовність визначається стадією розвитку дитини і може проявлятися без будь-яких особистих релігійних переконань, цінностей та звичаїв. Духовність пов'язана з підходом дитини до розуміння життя і включає такі проблеми, як безумовна любов, прощення, надія, безпека та спадок. Навіть у зовсім маленьких дітей може виникнути потреба обговорити, що таке помирання та потойбічне життя [11].

Більше десяти років тому дослідження показали, що діти, які живуть із захворюваннями, що загрожують життю, висловлюють думки та потребу щодо молитви та Бога [20]. Недавні дослідження показали, що багато онкохворих дітей та підлітків отримують втіху від надії та віри в Бога чи вищу силу, молитви чи читання Біблії. Хоча деякі діти та підлітки отримують такі позитивні результати, як покращення комфорту та здоров'я, пов'язані з їх духовністю, вони також іноді намагаються знайти сенс та мету в своєму житті [21].

Незважаючи на те, що дослідження досягли успіхів у вдосконаленні знань медичних працівників про духовність у паліативній допомозі, необхідні додаткові дослідження щодо духовних потреб педіатричних пацієнтів, які страждають та помирають від раку, та заходи, які можуть зменшити духовні страждання або сприяти їх духовному добробуту.

Завдання для поліпшення паліативної допомоги дітям

Прогалини в наданні фізичної, психологічної, соціальної та духовної підтримки дітям зі загрозливи- 
ми для життя станами підтверджують необхідність вдосконалення педіатричної паліативної допомоги для цієї групи пацієнтів. Таким чином, існують такі проблеми у паліативній допомозі для дітей, як: оцінка розуміння дітьми смерті та їх духовно-психологічна підтримка, заохочення раннього початку надання паліативної допомоги, що включає обговорення завершення життя, та покращення доступності дитячої паліативної допомоги.

Педіатрична паліативна допомога для онкологічних дітей та підлітків часто починається досить пізно. У багатоцентровому дослідженні, що включило шість лікарняних програм паліативної допомоги у США та Канаді, було виявлено, що середній час від початкової консультації до смерті склав 107 днів [22]. Близько 20 \% цих пацієнтів мали рак. Результати показали, що ці пацієнти частіше помирають протягом 30 днів після первинної консультації, ніж пацієнти 3 іншими діагнозами.

У дослідженні, що охопило 77 невиліковно чи хронічно хворих дітей, було показано, що середній час від прийняття рішення «не реанімувати» до смерті становив менше 24 год [23]. Лікарі ініціювали дискусії щодо смерті з помираючими підлітками або їх сім'ями в середньому за 30 днів до смерті. Перші об- говорення частіше відбувались на останньому тижні життя у підлітків із лейкемією/лімфомою.

Розмови, розпочаті на початку хвороби, не завжди повинні зосереджуватись на можливості смерті, але можуть повідомляти дитині, що двері відкриті для обговорення прогнозу. Медичні працівники, які проектують можливість відкрито та відверто відповідати на запитання дітей, пропонують необхідну підтримку дітям та їхнім родинам. Пізнє спілкування може залишити дуже мало часу для підготовки до смерті.

Медсестри, які доглядають онкологічних хворих, мають унікальну можливість покращити терміни надання послуг дитячої паліативної допомоги. Медсестри можуть бути зв'язком між педіатричним пацієнтом та родиною, медичною групою та командою дитячої паліативної допомоги для подолання проблем, які можуть заважати оптимальному догляду за пацієнтом.

Хоча команди дитячої паліативної допомоги не завжди доступні в кожному педіатричному онкологічному центрі, медсестри різних рівнів перебувають в ідеальному становищі для надання паліативної допомоги дітям та підліткам, хворим на рак, та їхнім сім'ям (табл. 1) [11].

\section{Таблиця 1. Роль медичної сестри з паліативної допомоги у дитячій онкології}

\begin{tabular}{|l|l|}
\hline \multicolumn{1}{|c|}{ Роль медичної сестри } & \multicolumn{1}{|c|}{ Роль медичної сестри з паліативної допомоги } \\
\hline $\begin{array}{l}\text { Оцінка фізичних, психологічних, соціальних та } \\
\text { духовних потреб пацієнта та сім'ї }\end{array}$ & $\begin{array}{l}\text { Забезпечення всебічної медико-психологічної оцінки пацієн- } \\
\text { та та його сім'їі }\end{array}$ \\
\hline $\begin{array}{l}\text { Оцінка ефективності плану лікування, включаючи } \\
\text { призначені ліки }\end{array}$ & Надання кваліфікованого та всебічного лікування симптомів \\
\hline $\begin{array}{l}\text { Підтримка лікаря або іншого члена команди в } \\
\text { лікуванні та навчанні сім'ї }\end{array}$ & $\begin{array}{l}\text { Сформулювати план паліативної допомоги; повідомляти } \\
\text { план пацієнту, родині та медичній команді; відстежувати/мо- } \\
\text { дифікувати план на основі потреб дитини та сім'ї }\end{array}$ \\
\hline $\begin{array}{l}\text { Повідомлення про потреби дитини та сім'ї медич- } \\
\text { ній бригаді }\end{array}$ & $\begin{array}{l}\text { Забезпечення послідовності догляду в різних медичних за- } \\
\text { кладах; надання допомоги лікарю з паліативної допомоги та } \\
\text { підтримка на рівні первинної медико-санітарної допомоги }\end{array}$ \\
\hline $\begin{array}{l}\text { Підтримка дитини та сім'ї у складних та делікатних } \\
\text { ситуаціях (наприклад відповісти на запитання та } \\
\text { занепокоєння, підтвердити план обстеження/ліку- } \\
\text { вання) }\end{array}$ & $\begin{array}{l}\text { Забезпечення розуміння пацієнтом та родиною плану до- } \\
\text { помоги та очікуваних результатів; навчання та керівництво } \\
\text { іншии медичними працівниками щодо основних принци- } \\
\text { пів паліативної допомоги }\end{array}$ \\
\hline
\end{tabular}

Висновки. Протягом останнього десятиліття були досягнуті успіхи в галузі дитячої паліативної допомоги. Однак потрібна додаткова робота для покращення життя та зменшення страждань для дітей, які живуть з онкологічними захворюваннями, та їхніх сімей.
Медсестри можуть стати місцевими, регіональними та національними лідерами в галузі паліативної допомоги та відповідних досліджень. Тільки тоді парадигма паліативної сестринської допомоги може бути зміщена на найвищий рівень і пропонувати найзаслуженішу допомогу дітям та підліткам, які стикаються, страждають та помирають від раку. 


\section{СПИСОК ЛІТЕРАТУРИ}

1. National Research Council. End-of-life care: special issues in pediatric oncology / J. Hilden, B. Himelstein, D. Freyer, S. Friebert, J. Kane, editors // Improving Palliative Care for Cancer. - Washington, DC: The National Academies Press. - 2001. - P. 161-198.

2. National Center for Health Statistics. United States: child mortality 2012. - URL: http://www.childdeathreview. org/national childmortalitydata.htm (дата звернення 19.04.2021).

3. Вороненко Ю. В. Створення системи паліативної та хоспісної допомоги в умовах реформування охорони здоров'я в Україні: медичні та соціальні аспекти [Електронний ресурс] / Ю. В. Вороненко, Ю. І. Губський, А. В. Царенко // Охорона здоров'я і суспільство. - 2014. № 1 (2). - С. 63-75. - Режим доступу : http://nbuv.gov.ua/jpdf/nauipr_2014_1_11.pdf (дата звернення 19.04.2021).

4. Слободюк 3. О. Паліативна допомога в неонатології та шляхи її розвитку / 3. О. Слободюк, Н. Б. Галіяш // Медсестринство. - 2017. - № 1. - С. 32-35. DOI: 10.11603/24111597.2017.1.8486.

5. Availability and use of palliative care and end-of-life services for pediatric oncology patients / D. L. Johnston, K. Nagel, D. L. Friedman [et al.] // J. Clin. Oncol. - 2008. No. 26 (28). - P. 4646-4650.

6. Bereaved parental evaluation of the quality of a palliative care program in Lebanon / R. Saad, HA-S. Huijer, S. Noureddine [et al.] // Pediatr. Blood Cancer. - 2011. No. 57 (2). - P. 310-316.

7. Integration of a palliative and terminal care center into a comprehensive pediatric oncology department / H. Golan, B. Bielorai, D. Grebler [et al.] // Pediatr. Blood Cancer. 2008. - No. 50 (5). - P. 949-955.

8. Place and provision of palliative care for children with progressive cancer: a study by the paediatric oncology nurses' forum/United Kingdom children's cancer study group palliative care working group /J. Vickers, A. Thompson, G. S. Collins [et al.] // J. Clin. Oncol. - 2007. - No. 25 (28). P. 4472-4476.

9. Сисоєнко І. Паліативна допомога дітям в Україні [Електронний ресурс] / І. Сисоєнко // Обозреватель. 2016. - Режим доступу : http://my.obozrevatel.com/ life/83174-paliativna-dopomoga-dityam-v-ukraini.htm (дата звернення 19.04.2021).

10. Friebert S. NHPCO facts and figures: pediatric palliative and hospice care in America; 2009. - URL : http://www.nhpco. org/files/public/quality/Pediatric_Facts-Figures.pdf.
11. Palliative nursing care for children and adolescents with cancer / T. L. Foster, C. J. Bell, C. F. McDonald [et al.] // Nursing: Research and Reviews. - 2012. - No. 2. - P. 17-25. DOI: $10.2147 /$ NRR.S25904.

12. Miller E. Nausea, pain, fatigue, and multiple symptoms in hospitalized children with cancer / E. Miller, E. Jacob, M. J. Hockenberry // Oncol. Nurs. Forum. - 2011. - No. 38 (5). P. 382-393.

13. Fatigue in children with cancer at the end of life / C. K. Ullrich, V. Dussel, J. M. Hilden [et al.] // J. Pain Symptom Manage. - 2010. - No. 40 (4). - P. 483-494.

14. Differences in symptom occurrence, frequency, intensity, and distress in adolescents prior to and one week after the administration of chemotherapy / A. J. Walker, V. Gedaly-Duff, C. Miaskowski, L. Nail // J. Pediatr. Oncol. Nurs. - 2010. - No. 27 (5). - P. 259-265.

15. An institutional quality improvement initiative for pain management for pediatric cancer inpatients / L. L. Oakes, D. L. Anghelescu, K. B. Windsor, P. D Barnhill // J. Pain Symptom Manage. - 2008. - No. 35 (6). - P. 656-669.

16. Carter B. Palliative Care for Infants, Children, and Adolescents: a practical handbook / B. Carter, M. Levetown. Baltimore : John Hopkins University Press, 2004.

17. Symptoms in the palliative phase of children with cancer / J. M. J. Theunissen, P. M. Hoogerbrugge, T. van Achterberg [et al.] // Pediatr. Blood Cancer. - 2007. No. 49 (2). - P. 160-165.

18. Aldridge A. Coping and adjustment in children with cancer: a meta-analytic study / A. Aldridge, S. Roesch // J. Behav. Med. - 2007. - No. 30 (2). - P. 115-129.

19. Cassano J. Talking with others who "just know": perceptions of adolescents with cancer who participate in a teen group / J. Cassano, K. Nagel, L. O'Mara // J. Pediatr. Oncol. Nurs. - 2008. - No. 25 (4). - P. 193-199.

20. Kamper R. Children with advanced cancer: responses to a spiritual quality of life interview / R. Kamper, L. Van Cleve, M. Savedra // J. Spec. Pediatr. Nurs. - 2010. - No. 15 (4). P. 301-306.

21. Flavelle S. C. Experience of an adolescent living with and dying of cancer / S. C. Flavelle // Arch. Pediatr. Adolesc. Med. - 2011. - No. 165 (1). - P. 28-32.

22. Pediatric palliative care patients: a prospective multicenter cohort study / C. Feudtner, T. I. Kang, K. R. Hexem [et al.] // Pediatrics. - 2011. - No. 127 (6). - P. 1094-1101.

23. End-of-life experiences in adolescents dying with cancer / C. Bell, J. Skiles, K. Pradhan, V. Champion // Support Care Cancer. - 2010. - No. 18 (7). - P. 827-835. 